\title{
Women Aesthetics in Pundi Bank Advertisement from Cultural Studies Perspective
}

\author{
Anak Agung Gde Bagus Udayana \\ Faculty of Fine Arts and Design (FSRD) Indonesia Institute of the Arts (ISI) Denpasar
}

bagusudayana@isi-dps.ac.id

\begin{abstract}
Women aesthetics that are visualized in the billboard advertisement of Pundi Bank is a strategic activity to persuade consumer or society. This is intended to see the picture of female aesthetics and its significance in contemporary society through the billboard advertisement of Pundi Bank by identifying the signs contained. The method that is used in this study is semiotics. Semiotics is essentially a qualitative interpretative (interpretation) method that focuses on sign and text as a study object as well as on how researchers interpret and understand the code (decoding) of the sign and the text. This study gives the aesthetic female image presented in the ad message it appears to be of the election of the visual communication element, It's like photographic illustration, text, and color. The elements are arranged in such a harmony with the use of asymmetrical balance, making it look more attractive with a protrusion on the photographic illustration. The meaning that is delivered by Pundi Bank from this advertisement is a reflection of women's lifestyle reality in contemporary society. Furthermore, this advertisement is formed by many icons in which it can be interpreted as a symbol of contemporary woman. Besides that, Pundi Bank advertisement also has a construction of social reality which can be seen as denotative and connotative meaning.
\end{abstract}

Keywords: billboard advertisement, women aesthetics, contemporary icons

\section{Estetika Perempuan dalam Iklan Pundi Bank dari Perspektif Kajian Budaya}

Estetika perempuan yang divisuliasasikan dalam iklan billboard bank Pundi merupakan kegiatan yang strategis untuk mampu mempersuasif masyarakat konsumen. Tujuannya agar gambaran tentang estetika perempuan dan makna perempuan dalam masyarakat kontemporer yang ditampilkan oleh bank Pundi melalui iklan billboardnya dengan cara mengidenfikasi tanda-tanda yang terdapat dalam iklan tersebut. Penelitian ini menggunakan metode semiotika. Metode semiotika pada dasarnya bersifat kualitatif interpretatif (interpretation), yaitu sebuah metode yang memfokuskan pada tanda dan teks sebagai objek kajiannya, serta bagaimana peneliti menafsirkan dan memahami kode (decoding) dibalik tanda dan teks tersebut. Hasil penelitian ini memberikan gambaran estetika perempuan dihadirkan dalam pesan iklan itu tampak dari pemilihan unsur-unsur komunikasi visualnya, seperti ilustrasi fotografi, teks, dan warnanya. Unsur-unsur tersebut ditata sedemikian rupa secara harmonis dengan menggunakan keseimbangan asimetris, menjadikannya nampak lebih menarik dengan penonjolan pada ilustrasi fotografinya. Makna yang diciptkan iklan bank Pundi merupakan cerminan realita gaya hidup perempuan pada masyarakat kontemporer. Iklan bank Pundi juga banyak terbentuk oleh ikon-ikon yang dapat dimaknai sebagai simbul perempuan kekinian. Iklan bank Pundi juga memiliki konstruksi realitas sosial yang dapat dimaknai sebagai makna Denotatif dan Konotatif.

Kata kunci : iklan billboard, estetika perempuan, ikon-ikon kontemporer

Peer review : 9 - 23 Agust 2018, Accepted : 3 September 2018 


\section{INTRODUCTION}

Advertisement is a very importantaspect in company's marketing. Advertisement is the most popular visual communication media and the most potential marketing medium for anyone including individuals, private companies, and the government at the present. Women aesthetics in an advertisement visualization are expected to sell products or services as well as generate public interest to have or to take action towards it.

Advertising activity is considered to be able to affect the consumption trends in society. Advertisers can also change public knowledge about the characteristics, information, presence, and the value of the advertised product. An advertisement designer often create aesthetic element through women's appearance to attract public attention. This is happened due to the consideration that female aesthetics have a visual appearance that can affect people, especially men, to perform actions offered by the company. So, the use of women in an advertisement is seemed to be in line with the ideology of capitalism. Capitalism ideology plays with the desire of ourselves to generate profits; a photo of a woman can be used as an attraction to playing people's desire, particularly men, in an advertisement. This is similar to the research of Piliang (2010: 220), he stated that capitalism is a space in which it contains the circulation of desire. Through the rotating desire machine, capitalism could create a network of semiotics and generate the human character of consumption. Women aesthetics in the display of advertisement will make the ad more attractive to be enjoyed. Therefore, women that are visualized in an advertisement will be able to attract attention, direct mind and desires, as well as convince the consumers about the importance of the thing that is displayed in the advertisement by offering benefits that suit their needs. The aesthetics appearance of women visualization in an advertisement to attract consumers' attention can be interpreted as a veiled hegemony of capitalism. According to Piliang (2010: 220), the covert terror carried out by capitalism through a network of semiotics in life (lifestyle and appearance) is intolerable for the public as consumers. The use of women in an advertisement is closely related to the ideology of capitalism that places women as one of production means. Thus, the focus on the aspects of beauty, elegance, and body has potentially affected the belief that women's value is only depended on the physical attraction or appearance (biological and its nature). By that, women aesthetics in such advertisement can provide attraction and form women's ideology of whom can be categorized as an ideal, pretty, successful, and beautiful woman.

Nowadays, women's lifestyle in contemporary society is a good thing to be used in the visual advertisement. Women who appear in the advertisement represent a life growing reality in contemporary society even though it is not necessarily so true. The image of women as a lifestyle can lead to different perceptions due to the blending of lifestyle in contemporary society. Lifestyle becomes important in this kind of society in which it makes appearance and self-image included in the list of consumption and commodities; anything that forms lifestyle will be a commodity and consumerism thing. Indeed, a product is likely to use the power of women's feature as a metaphor for contemporary society.

The social phenomenon of women's image in an advertisement that is seen from cultural studies perspective could trigger the pros and cons of various circles. Actually, this phenomenon is an interesting thing to be observed because each of the consumptive society will have a different view about advertisement in contemporary society. In this study, the writer will look for the aesthetics and meaning behind an advertisement that uses women in its visual appearance.

From several bank advertisements that are displayed around Denpasar, Bali, Pundi Bank is the only company which conveys its message through outdoor advertising by using women visualization. Outdoor advertising is expected to contain a wide charge of aesthetics, function, and meaning, as well as a set of visual aspects that can be used as a tool to deliver a message from its illustration, color, typography, and text. This whole visual aspect is a sign which acts as a representation of the message in which we want to convey. Therefore, the formulation of the problem in this study is 1 . How is the Women Aesthetics in Pundi Bank Advertisement? 2. What is the Meaning Behind Women Visualization in Pundi Bank Advertisement?

Based on the problems above, the writer is interested in doing a research on Pundi Bank advertisement. The purpose is that the writer wants to deepen the knowledge about the message, signs, icons, and symbols in the ad which represent the social reality of contemporary society. Advertising is closely related to the meaning of consumer; consumers can produce a different meaning to what is offered by media texts. They are not only seen as a connoisseur of media content advertising but also a producer of meaning. The meaning of a text or message in an advertisement comes from consumers so that anything offered will not always generate the same meaning. Precisely, meaning is formed when the message is being received in which it also depends on the diversity of contemporary society. From here we can say that the aim of this study is to determine the image of women aesthetics in Pundi Bank advertisement. In addition, this research also able to describe the overall meaning of women visualization in contemporary society displayed by Pundi Bank through its billboard advertisement, by identifying the signs contained in the ad.

Furthermore, the benefit of this writing for academicians is a guide to increase the number of references and as a medium for the development of cultural studies science in Visual Communication Design. This study is also ex- 
pected to be a source of information for academicians that the aesthetics of women in contemporary society can be delivered through the visualization of advertising media and interpreted by the discourse of women in advertising products. Other than that, this study can be a conceptual contribution to the development of further research that is related to the issue of women in advertising media.

\section{METHODS}

The method that is used in this study is semiotics method. Essentially, semiotics is a qualitative interpretative (interpretation) method that focuses on sign and text as a study object as well as on how researchers interpret and understand the code (decoding) of the sign and the text. (Arsana, 2012: 8)

According to Piliang and Barker, semiotics is a science that examines the signs as part of social life. (Arsana, 2012: 9). This definition can be understood as a "system of signs" which also can be interpreted in contemporary life. Hence, the existence of semiotics is very central in cultural studies. (Arsana, 2012: 9). Text in its simplest sense is a combination of signs. (Piliang, 2003: 270). The text is not only in the form of writing creation but it includes design objects such as an advertisement, fashion, and etc as what have been mentioned by Piliang (2003: 270). Piliang in his research believed that the meaning of a text can be considered as a collection of signs and objects of any design (advertising, architecture, interior, product, fashion). By that, due to its elements combination of signs with such codes and rules, it will certainly produce a meaningful expression.

Semiotics is a structured analysis of where each sign or symbol always has an underlying structure so that when it reveals a particular meaning, it is influenced by myth, ideology, and hegemony developed in the community. Piliang (2003: 271) explained what is meant by signs worked through myth is actually how culture explains or understands some aspect of the reality and natural phenomena. Ideology is something that is abstract and can be found in the text by examining the connotation within. In correlation with that, mythology presents the meaning which has a point in ideology. Ideology must be able to be told and the story formed is called a myth. On the other hand, hegemony is defined as the power of structure associated with language system which is the preconditions of parole (language users).

One area of semiotics in cultural studies is advertising. Advertising is a relevant field of study that uses semiotic methods. The advertisement is visualized with signs. Signs cover a system that works well together to achieve the desired effect. The most important element in advertising is image and text: the written word which also explains the image. Moreover, semiotics system which we can found in advertising is the use of iconic signs which in turn displays a similar circumstance with our reality; these signs describe something. Ad appearance is a representation of contemporary society where the reflection is illustrated as a form of realities in contemporary society based on codes, conventions, and culture ideologies. The approach to mass culture or popular culture (pop culture) as opposed to moralistic approach is specifically referred to high culture. Ardono has developed the concept of cultural industry which denotes to the way entertainment and media become an industry of capitalism in circulating cultural commodities and in manipulating human consciousness (Agger, 2008: 180). In the postmodern era or capitalism, pop culture seems to overwhelm our lives, it surrounds us with Baudrillardian simulation that blends into a thick issue of representation and image (Agger, 2008: 181). Capitalism spreads quickly with advertisement visualization in which it is difficult to be critically noticed because it is enclosed with the illusion that the cultural industries bring us to reality. Thus, what is meant by cultural industry in this study is referred to mass culture and high culture which creates capitalism industry in the postmodern era.

Cultural industry in postmodern era is a sociocultural phenomenon which always shows eroticism or pornography. For that reason, there is a profound difference between high culture and mass culture which equally produces capitalism in the cultural industry. In this issue, mass culture is assumed as a destroyer of morality which has low value while high culture is considered as a keeper of morality which has noble value. This is in line with the opinion of Ardono (Agger, 2008: 180) that pop culture, in this case, is a model of capitalism ideology which does not offer an indisputable doctrine or thesis about the necessity and rationality of today's community, yet it only provides a short-term addiction that distracts people from their problems and idealized the present time with the representation of fun experience.

The study of mass culture as an industry of capitalism culture is cannot be separated from media which is particularly the printed media and more specifically the billboard. That is where the industry of capitalism culture gets its spot. Culture is produced in a massive way, and of course, through the process of visual communication design. Women are more widely used as the visual objects in the industry of this capitalist culture. The attractiveness of female body can be associated with sex that is solely attached to it.

Look at the ads that promote products on television. The products which absolutely had no relationship with sexuality are designed in such a way for the advertising purpose in which it almost always involves women's feature. For an instance, a brand of paint, in its advertisement, the commercial star is set in bed with her husband saying the phrase, "no drop anti bocor", bocor....bocor or in another 
version, "nakal".

Anyone knows that paint or wall coating product has neither direct nor indirect connection with sexual activity. So, the question is that why there is such scene in bed? What is the association with the product being advertised? Well, there is absolutely no connection. The visualization appears solely as a symbolization so that consumers will form a thought on the advertised products. If the products which have no connection with sex are designed in such a way by the designer, then the visualization of the ad can be predicted as it is directly related to the sex thing.

Capitalism entered the narrow area as it is gained a wide access to offer product or service. Therefore, consumer or society will be stuck in the frame of capitalism which represents the reality of women's body as a symbol of "good consumption" in which it easily attracts attention. Capitalism which uses the female feature in producing cultural industry through its billboard appearance is without question an option that is economically very rational. That kind of cultural industry can be very tempting, aspirational, and arose consumer lifestyle which in the end is merely a body exploitation to its visual appeal.

The theory is a collection of concepts which suggests a systematic view of a phenomenon developed in the community so that it could give an explanation and overview of the issues. In this study, semiotics method is used in order to assess the aesthetics and meaning of women figure in Pundi Bank billboard advertisement in contemporary society.

In semiotics, we will see that media text is part of the signs. As what we have mentioned before, semiotics itself is the study of signs. Kusrianto (2007: 58) in his research explained that semiotics is derived from the Greek, namely "sema" which means sign. The term semeiotikos means the interpretation of signs. Semiotics was originally developed in the field of language which then brought to be developed in the field of art design.

Semiotics in this study is used to analyze the women aesthetics in Pundi Bank advertisement in contemporary society with the assumption that this advertisement is communicated through a set of signs. Thus, Saussure approach is used as the semiotics method in this study. This approach describes signs as a union of inseparable two fields in which it is called as a signifier; signifier is the material aspect of a sign. Furthermore, the second field of sign mentioned by Saussure is a signified. Signified itself is represented materially by signifier (Cobley and Jansz, 2002: 11). This statement is also in line with the research of Piliang (2012: 322 ), structurally, an advertisement consists of signs; signs are the smallest element of language that consists of signifier, something that is materially in the form of pictures, photographs, illustrations, and signified; signified is a con- cept or meaning that is derived from the signifier, all of which can describe the realities that exist in society.

Signs can also be seen from the social conventions in between language users. A word has a particular significance due to the social agreement of language users that is in concern with the meaning of the language. For an instance, a word "phone" is known as a means of communication via voice. In some complicated issues, semiotics will try to probe the nature of the sign system, as stated by Sobur (2001: 126), semiotics will try to find the meaning of a complex, hidden, and cultural media texts. Consequently, this raises an attention to the additional or secondary meaning (connotative) and primary meaning (denotative). Denotation has a direct meaning in which this can be regarded as the first signifier. For example, the word "roses", has a denotative meaning of "part of a flowery plant, could be in red, white, or yellow with a thorny stem". Afterward, the connotative meaning of "roses" will be slightly different and is associated with contemporary culture. The meaning within will be linked with contemporary culture such as flower is interpreted as an affection, expression of happiness, sadness, and others. Piliang (2012: 322) said that denotative meaning is explicit on which it is based on what has been appeared. While on the other hand, connotative meaning has a deeper meaning which relates to cultural understanding and ideology. An advertisement is usually composed of three elements of signs, namely the image of an object or product being advertised, the picture of objects in its surrounding area that gives context to the objects, and lastly, typography, color, and text.

\section{DISCUSSION}

The topic of this research is still relatively rare and original seen from several books observation and from the results of previous research. However, there are many references which have a correlation to the title of this study so that it is expected to support the literature of the study.

One of the references that are related to this study refers to the research of Ratna Noviana (2002) published in a book entitled "Jalan Tengah Memahami Iklan: Antara realitas, representasi dan simulasi". This book talks about the phenomenon of advertising that is understood as texts and texts as signs. Texts that occurred in an advertisement can be translated with the interpretation of post-structuralist deconstruction. There are five examples of texts which become the sample in this study such as: "Waktu Unjuk Gigi" from Sampoerna A-Mild Cigarette, "Siapa Takut" from Clear Menthol Shampoo, "Wanita-Wanita Lux" from Lux soap, "Mentari Pagi Bromo" from Sari Ayu Cosmetics, and "Bangunlah" from Tempo weekly magazine.

The women who are always displayed in an advertisement try to create a self-image that is intended to manipulate its external appearance so that it could attract consumers. In 
an advertisement, consumer's taste is formed through the presence of women in which it is able to create passion and social symbol. On the other hand, advertising activity is also capable of affecting contemporary society to be more interested and build a strong desire to their needs in the form of excessive desire towards the goods that are not really essential.

Women aesthetics in an advertisement not only act a symbol of female domination but more on a symbol of exploitation in a broader sense. Women exploitation gives meaning to the power of capitalism in the cultural industry to undertake any action which allows financial profit including the display of women beauty in a billboard advertisement. This is intentionally done in order to raise the desire of consumers to buy the material presented. It basically shows that the beauty of the female body is a significant potential to attract consumers, one of which is through billboard advertisement. Women aesthetics, in this case, are visualized through photographic techniques. Photography is chosen in order to visualize the female figure so that the model can be seen realistically. In addition to photography illustration, the billboard advertisement in Pundi Bank also completed its design with typography. The typography that is used by Pundi Bank is the unrelated typography which is often called as the san serif. One letter of san serif font in Pundi Bank advertisement displays a simple look by accentuating the headline of the overall design. Besides that, in the choice of colors, Pundi Bank uses monochrome as the dominant color in its billboard so that it could deliver the aesthetics aspect that consumer wants to see. Women aesthetics which are visualized in Pundi Bank billboard present an asymmetrical composition either in the placement of photographic illustrations, headline text, or color. This composition is able to attract consumers' attention and is expected to inspire consumers to take action towards the objectives of Pundi Bank ad. The billboard advertisement as shown below is managed to create women aesthetics in informative, communicative, elegant, harmonious, and surprising appearance.

As we can see above, this ad shows three beautiful young women dressed in red and blue working clothes. The style of those clothes plays an "index" of someone who works in an office or we called it as young entrepreneurs. One of the women with "name tag" (an icon of bank employee) gives flowers to one of the women as displayed in the advertisement. In details, the women dressed in red and wore a name tag on its front pocket who acts as the icon of bank employee could be a sales marketing, teller, leader, or others. Meanwhile, the one who receives the flower is the icon of bank consumer in which she gets a facility from Pundi Bank in the form of "flower" (bank interest). On the left, there is a young woman holding a passbook and shows an excitement. Passbook is one of the bank icons as it is also included in Pundi Bank service. Also, in the illustration above, there is Pundi Bank logo in the shape of logotype and logogram. The logotype is a logo which consists

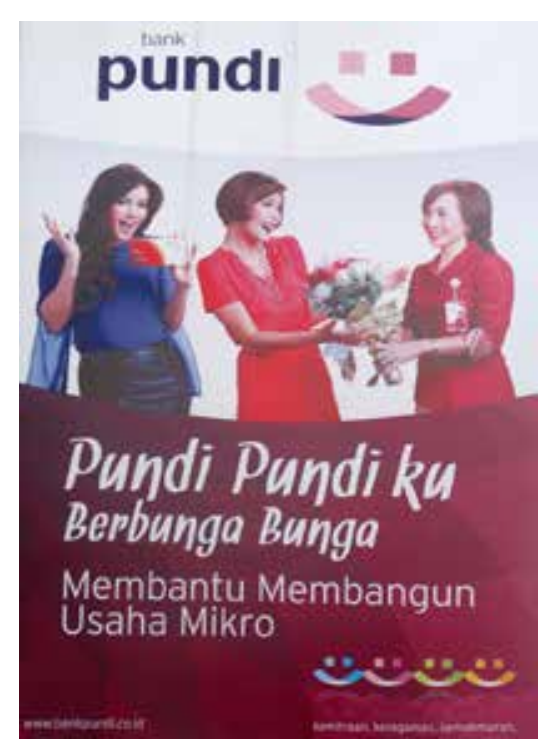

Figure 1. Pundi Bank Billboard Advertisement in Denpasar

(Source:Survey, 2013)

of typography elements while logogram is a logo which is compiled from graphical or imagery elements or a combination of text and image. As stated by Rustam (2009: 22), a logo is generally divided into three types: 1) picture marks and letter marks, image and text is separated, 2) picture marks with letter marks, could be called as an image or as a text, these two elements are blended, 3 ) letter marks, there is only the written element. Then, at the bottom section, there is a verbal message presented in three typography. The text is read "Pundi Pundi ku Berbunga Bunga" in which it is written in a larger font in the first text. After that, in the second text, the letter is presented in a different font. This message is actually explaining the way to build micro-enterprises. Lastly, is the closing slogan and web address of Pundi Bank. From this verbal message, we could know the target consumers chosen in the ad. The use of typography in the message is composed of two types, all impressive, informal, pleasant, and flexible.

In terms of visual aesthetics, female workers or employers who become models in the advertisement appear almost in a full body so that it is illustrated prominently in the display. This indicates that the advertised product is for people who already settled financially or for entrepreneurs who want to increase its interest. Moreover, the face of the models reflects a cheerful or happy expression due to what she has achieved from the bank.

If we assess this advertisement from denotative level, there are three women who have a role as the models. All of those three women are shown almost in full body and dominated the visualization. They have almost the same face expression which is cheerful and unpretentious by presenting the visualization of passbook and flower. It is, of course, intended to mark the joy that is obtained or provided by the advertiser. The happy impression is highlighted by the color of the background which is monochrome. Psychologically, monochrome implies warmth and femininity. The flower that is shown in the visualization can 
be interpreted as a flower bouquet which could be marked as a gratitude, love, greeting, and so forth; the flower is part of the plant and is given to someone. In general, the visual side of this ad tells that the three beautiful women are an ideal and perfect figure in which it is also supported with a hardworking, gentle, sympathetic, achieving, success, and logical character growing in contemporary society. These women are supposed to be imitated and promoted by the contemporary society.

If the verbal and visual message is associated, the message that is conveyed by this advertisement at connotative level is that saving is part of the lifestyle of office workers and young entrepreneurs. With saving, we would gain an interest; more savings will generate more interest. We can see this message from the visualization of Pundi Bank employee who gives a flower to one of the women in the billboard advertisement. This meaning is emphasized by the verbal element of "Pundi Pundi ku Berbunga Bunga". Pundi (a mold to hold water or a container for something) can be interpreted as a place to put money or jewelry by the traditional people. "Berbunga Bunga" is also seen as a blooming flower that keeps on flowering and blooming.

Women's lifestyle in contemporary society is identified with beauty, excitement, body appearance, and success. In this case, it becomes the primary visualization in Pundi Bank advertisement. Cultural industry makes a very common phenomenon and women aesthetics to be the main target in the society, it is clearly visible that women are used on behalf of a marketing issue. Women aesthetics are often used on beauty products, its body appearance is seen as an ideal way to achieve the ultimate goal. By using women aesthetics, anything like success, popularity, and happiness can be achieved.

\section{CONCLUSION}

Women aesthetics which can be seen in Pundi Bank advertisement was analyzed based on semiotics theory to obtain denotatives meaning. Those can be revealed from the selection of visual communication elements such as photographic illustrations, text, and color. Those elements are arranged in a manner of harmony with the use of asymmetrical balance, making it look more attractive with a protrusion on the photographic illustration. The use of women illustrations could create female aesthetics which are communicative, informative, surprising, and persuasive. Ideologically, the creation of women aesthetics will be succeeded if the women show beauty, elegance, good body figure, gratitude, happiness, good dressing, and cleanness. On other side, conotatives meaning will be led people to take the conditions as described above even though it is already clear that is not necessarily true. In other words, that is actually a distortion of reality.

The meaning created by Pundi Bank advertisement that highlighted the aesthetics of women is a reflection of women's lifestyle reality in contemporary society. The visualization in this advertisement is actually targeted to create a self-image that is intended to manipulate the external appearance so that it could attract consumers. The women presented in the advertisement are considered as a means of consumer's taste creation, desires production, and social symbol establishment. Therefore, this Pundi Bank advertisement can influence the contemporary society to be more interested and to have a strong desire in the form of excessive desire towards the goods that are not really essential. This advertisement is also formed by many icons which can be interpreted as a symbol of contemporary woman. The text compiled in this ad is also able to respond the developments in contemporary society. A text in this adhas a role in conveying the businessmen desire to influence consumers. The advertisement also has a social construction of reality which can be interpreted as a denotative and connotative meaning.

\section{ACKNOWLEDGMENTS}

Through this opportunity, we would like to thank the honorable, the Rector of Indonesian Arts Institute of Denpasar, Prof. Dr. I Gede Arya Sugiartha, S.Skar.,M.Hum, and Mrs. Dra. Ni Made Rinu, M.Si as the Dean of Faculty of Art and Design as well as the Chairman of the Institute of Research and Community Service in Indonesian Arts Institute of Denpasar, Dr. Drs. I Gst Ngurah Ardana, M.Erg in concern to the encouragement and opportunity that is given to do this research. We also like to thank the respondents and resources of advertising in Bali because they all sincerely and openly provide the information that is required for the completion of this study.

\section{REFERENCES}

Agger Ben. 2008. Teori Sosial Kritis, Kritik, Penerapan dan Implikasinya. Yogyakarta: Kreasi Wacana

Arsana I Gst Kt Gde. 2012. Aspek Epistemologi (Cara Kerja Keilmuan Kajian Budaya). Matrikulasi S3 Kajian Budaya Univ Udayana. Denpasar

Coble, P dan Janz,L. (2002). Semiotika for Beginners. Miza Media Utama: Bandung

Noviana Ratna. 2002. Jalan Tengah Memahami Iklan: antara Realitas, Representasi dan simulasi. Yogyakarta: Pustaka Pelajar

Kusrianto, A. (2007). Pengantar Desain Komunikasi Visual. Graphic Advertising Multimedia. Andi: Yogyakarta

Piliang, Yasraf Amir. 2003. Hipersemiotika Tafsir Cultural Studies atas Matinya Makna. Bandung:Jalasutra.

Piliang, Yasraf Amir. 2010. Post-Realitas: Realitas Kebu- 
dayaan dalam Era Post-Metafisika. Yogyakarta:Jalasutra

Piliang, Yasraf Amir. 2012. Semiotika dan Hipersemiotika.

Kode, Gaya dan Matinya Makna. Bandung:Matahari

Rustam S,S.Sn. 2009. Mendesain logo. Jakarta:PT Gramedia Pustaka Utama

Zoest, A V. (1993). Semiotika, Tentang Tanda, Cara Kerjanya, dan Apa yang Kita Lakukan Dengannya. Yayasan Sumber Agung: Jakarta. 